\title{
OPTIMIZATION OF NICKEL EXTRACTION FROM LATERITIC ORE IN HYDROCHLORIC ACID SOLUTION WITH HYDROGEN PEROXIDE BY TAGUCHI METHOD
}

\author{
1Ali ARAS, 2 Tevfik AĞAÇAYAK \\ 1,2Selcuk University, Department of Mining Engineering, Campus, Selcuklu, Konya, TURKEY \\ 1aliaras@selcuk.edu.tr, 2tevfik@selcuk.edu.tr
}

(Geliş/Received: 24.02.2017; Kabul/Accepted in Revised Form: 22.03.2017)

\begin{abstract}
Taguchi optimization method was used to determine optimum conditions for the extraction of nickel from lateritic ore in hydrochloric acid solution with hydrogen peroxide. Leaching time, stirring speed, temperature, hydrochloric acid concentration and hydrogen peroxide concentration were chosen as parameters. The optimum conditions for dissolution w ere found as leaching time of 240 min, a temperature of $70^{\circ} \mathrm{C}$, hydrochloric acid concentration of $3 \mathrm{M}$, hydrogen peroxide concentration of $0.1 \mathrm{M}$ and without stirring. The experimental results under optimum leaching conditions, showed that the extraction of nickel from lateritic ore was $90.66 \%$. Analysis of variance (ANOVA) was applied to experimental results. Percentage contributions of each factor for the extraction of nickel were determined.
\end{abstract}

Key Words: Leaching, Lateritic ore, Nickel; Hydrochloric acid, Hydrogen peroxide; Taguchi method

\section{Nikelin Lateritik Cevherden Hidrojen Peroksitli Hidroklorik Asit Çözeltisinde Çözündürülmesinin Taguchi Yöntemiyle Optimizasyonu}

ÖZ: Nikelin lateritik cevherden hidrojen peroksitli hidroklorik asit çözeltisinde çözündürülmesinin optimum koşullarını belirlemek için Taguchi optimizasyon yöntemi kullanıl mıştır. Deney parametreleri olarak, süre, karıştırma hızı, sıcaklık, hidroklorik asit derişimi ve hidrojen peroksit derişimi seçilmiştir. Çözündürme için optimum koşullar, karıştırma yapılmadan, 240 dakika liç süresi, $70{ }^{\circ} \mathrm{C}$ sıcaklık, $3 \mathrm{M}$ hidroklorik asit derişimi ve $0.1 \mathrm{M}$ hidrojen peroksit derişimi olarak bulunmuştur. Optimum koşullarda yapılan deney sonuçları, nikelin lateritik cevherden çözündürülmesinin $\% 90.66$ olduğunu göstermiştir. Deney sonuçlarına varyans analizi (ANOVA) uygulanmış ve her faktörün nikel çözündürülmesine olan katkısı belirlenmiştir.

Anahtar Kelimeler: Liç, Lateritik cevher, Nikel; Hidroklorik asit; Hidrojen peroksit; Taguchi metodu

\section{INTRODUCTION}

Nickel is a widely used metal due to its chemical and physical properties, such as corrosion resistance, alloying, electrical, thermal and catalyst properties. The main use area of nickel is the production of stainless steel and alloys, other uses are electroplating and chemistry. Laterites are oxide ores widely distributed in the equatorial regions. Lateritic nickel deposits occur during laterization, namely, a weathering process of ultramafic rocks containing minerals such as olivine, pyroxene and amphibole (Golightly, 1981). Ni-laterites can be classified in three main groups as oxide, hydrous silicate and clay silicate deposits (Golightly, 1981; Gleeson, et al., 2003; Brand et al., 1998; Sagapoa et al., 2011; 
Georgiou and Papangelakis, 1998). Nickel laterites constitute an important part of world reserves of nickel. About $70 \%$ of the world's nickel reserves occur from laterite deposits, the rest of sulphide deposits (Elias, 2002; Landers et al., 2009; Soler et al., 2008). However, about 40\% of the world's nickel production is provided from lateritic ores (Gleeson, et al., 2003; Elias, 2002; Brand et al., 1998; Dalvi et al., 2004). Nickel production from lateritic ores contains pyrometallurgical and hydrometallurgical processes (Deepatana et al., 2006). Generally, pyrometallurgical processes (ferronickel and matte smelting) involve drying, calcining/reduction and electric furnace smelting. How ever, hydrometallurgical processes can be applied as the Caron process, HPAL (High pressure acid leaching), AL (Atmospheric leaching) and acid heap leaching (Dalvi et al., 2004). In the literature, there are several studies related to lateritic nickel leaching in different solutions using high pressure or atmospheric pressure (agitation or heap leaching). The solutions used in these studies can be given as sulphuric acid (Georgiou and Papangelakis, 1998; Agacayak and Zedef, 2012; Luo et al., 2010; Stopic et al., 2002; Ayanda et al., 2011; Rubisov et al., 2000; Agatzini-Leonardou and Zafiratos, 2004; McDonald and Whittington, 2008a; Thubakgale et al., 2013; Landers et al., 2009; Mohammadreza et al., 2014), hydrochloric acid (Ayanda et al., 2011; Park and Nam, 2008; Agacayak et. al., 2011; Olanipekun, 2000; Wang et al. 2012; Guo et al., 2015; McDonald and Whittington, 2008b; Li et al., 2012), nitric acid (Agacayak and Zedef, 2013; Ayanda et al., 2011; Ma et al., 2013), ammonia (Zhai et al., 2010; Chen et al., 2010; Zuniga et al., 2010), citric acid, oxalic acid and acetic acid (Sahu et al., 2011; Behera et al., 2010; Sukla and Panchanadikar, 1993, Kursunoglu and Kaya, 2015). The main aim in leaching studies is to provide metal extraction with high recovery. Therefore, optimization of leaching parameters is very important. Taguchi method is widely used in optimization studies, both leaching studies and other scientific fields (Bese et al., 2010; Abali et al., 2006; Demir and Donmez, 2008; Babaei-Dehkordi et al., 2013; Asl et al., 2015; Dogan and Yartasi, 2014; Copur, 2002; Abali et al., 2011; Moghaddam et al., 2006; Ata et al., 2001; Safarzadeh et al., 2008; Ilyas et al., 2010; Zolfaghari et al., 2011). One of the advantages of Taguchi method is to keep costs to a minimum level compared to conventional experimental design methods and closer performance to the desired level. Another advantage is to adapt optimum conditions obtained from laboratory studies to real production conditions (Taguchi, 1987; Demir and Donmez, 2008; Donmez et al., 1998; Ata et al., 2001; Roy, 1995; Safarzadeh et al., 2008).

The dissolution of lateritic nickel ore in hydrochloric acid solution with hydrogen peroxide was investigated. As a result of the literature review, no study was found on the optimization of the dissolution of lateritic nickel ore for this medium. Hence, it was aimed to determine optimum leaching condition of lateritic nickel ore by Taguchi method.

\section{MATERIAL AND METHOD}

Lateritic nickel ore sample was taken from the Gördes (Manisa) region of Turkey. The sample used was a typical limonitic laterite ore with high iron content. According to the mineralogic analysis, the sample contains goethite, hematite and quartz. The XRD pattern of the sample was given in Figure 1. 


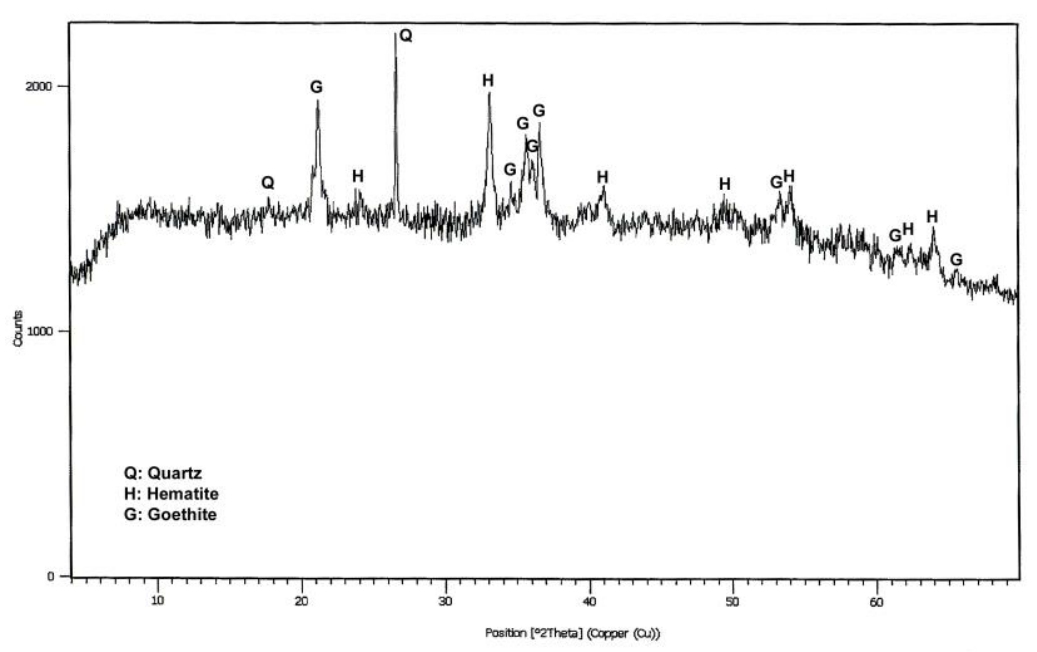

Figure 1. XRD pattern of the sample

First, the sample was ground to $-212 \mu \mathrm{m}$ in order to use in the experiments. Then, the sample was wet sieved to obtain different particle size fractions as $-212+150,-150+106,-106+75$ and $-75+53 \mu \mathrm{m}$. Nickel and iron contents were determined with Atomic Absorption Spectrophotometer (AAS). Nickel and iron contents of each size fraction were given in Table 1.

Table 1. Nickel and iron contents of each size fraction

\begin{tabular}{|lll|}
\hline Particle size, $\boldsymbol{\mu m}$ & Ni content, $\%$ & Fe content, $\%$ \\
\hline$-212+150$ & 1.05 & 36.01 \\
$-150+106$ & 1.02 & 37.03 \\
$-106+75$ & 1.00 & 36.40 \\
$-75+53$ & 1.01 & 38.25 \\
\hline
\end{tabular}

Leaching experiments were carried out in a $1 \mathrm{~L}$ glass vessel placed in a thermostatically-controlled water bath. For the stirring process, Heidolph brand RZR 2021 model mechanical stirrer equipped with a Teflon-covered propeller was used. For each experiment, $5 \mathrm{~g}$ lateritic nickel ore sample with a fraction size of $75 \times 53 \mu \mathrm{m}$ was used in $500 \mathrm{~mL} \mathrm{HCl}+\mathrm{H}_{2} \mathrm{O}_{2}$ solution. Taguchi method was used in the design of leaching experiments. Experimental parameters were applied as stirring speed (0-600 rpm), temperature $\left(40-70{ }^{\circ} \mathrm{C}\right), \mathrm{HCl}$ concentration $(0.5-3.0 \mathrm{M}), \mathrm{H}_{2} \mathrm{O}_{2}$ concentration $(0.1-1 \mathrm{M})$ and leaching time (30-240 min). At the end of leaching time, $5 \mathrm{~mL}$ solution was taken and diluted with distilled water to $100 \mathrm{~mL}$ in a volumetric flask. The amount of $\mathrm{Ni}$ in the leaching solution was determined using a GBC mark SensAA model flame atomic absorption spectrometer (AAS).

\section{RESULT AND DISCUSSION}

\section{Taguchi Method and Optimization Studies}

For optimizing a process by using Taguchi method, the design of an experiment involves the following stages: selection of independent process parameters; determination of the number of levels for the process parameters; selection of the suitable orthogonal array and assignment of the process parameters; performing the experiments proper to the orthogonal array; calculation of the performance characteristics; analyzing the data using the performance characteristics; determination of the optimum levels of the process parameters; performing the confirmation experiment using the optimum process parameters (Bese et al., 2010; Phadke, 1989; Abali et al., 2006). The change in the quality characteristics in reply to a factor presented in the experimental design is the signal of the requested effect. The noise is 
the effect of external factors that were not designed in experiments on the outcome. The signal to noise ratio $(\mathrm{S} / \mathrm{N})$ shows the sensibility of the quality characteristic to noise factors (Roy, 1995). Usually, three different equations of $\mathrm{S} / \mathrm{N}$ ratio were used depending on performance characteristics. These are, lower is better, nominal is best and higher is better (Roy, 1995; Atil and Unver, 2000; Zolfaghari et al., 2011). The aim of this study was to provide maximum metal extraction, "higher is better" which given in Equation (1) was used,

$$
\mathrm{S} / \mathrm{N}=-10 \log _{10}\left[\frac{1}{n} \sum\left(\frac{1}{E_{o M}}\right)^{2}\right]
$$

where $n$ is the number of repetitions of the experiments and $E o M_{i}$ (the extraction of metal) is the result of the experiment. Experimental factors and their levels were given in Table 2. The orthogonal array (OA) experimental design plan (L16) was given in (Table 3). EoM1 and EoM2 show the extraction of metal for the first and second leaching test, respectively. As seen from Table 3, the maximum $S / N$ value which obtained from test 10 was represented in bold. To investigate the optimum conditions, the analysis of the means (ANOM) statistical method was used. For that reason, the mean of the S/N ratios calculated and the mean of the $\mathrm{S} / \mathrm{N}$ ratios of factor $I$ in level $i$, is given by Equation (2):

Table 2. Experimental factors and their levels

\begin{tabular}{|l|lllll|}
\hline Factor & Description & Level 1 & Level 2 & Level 3 & Level 4 \\
\hline A & Leaching time $(\mathrm{min})$ & 30 & 60 & 120 & 240 \\
B & Stirring speed $(\mathrm{rpm})$ & 0 & 200 & 400 & 600 \\
C & Temperature $\left({ }^{\circ} \mathrm{C}\right)$ & 40 & 50 & 60 & 70 \\
D & Acid concentration $(\mathrm{M})$ & 0.5 & 1 & 2 & 3 \\
E & $\mathrm{H}_{2} \mathrm{O}_{2}$ concentration $(\mathrm{M})$ & 0.1 & 0.3 & 0.5 & 1 \\
\hline
\end{tabular}

Table 3. Experimental results and $\mathrm{L}_{16}\left(4^{5}\right)$ plan table

\begin{tabular}{|c|c|c|c|c|c|c|c|c|}
\hline \multirow{2}{*}{ Test } & \multicolumn{5}{|c|}{ Factor } & \multicolumn{2}{|c|}{$\operatorname{EoM}(\%)$} & \multirow{2}{*}{$\mathrm{S} / \mathrm{N}$} \\
\hline & $\mathbf{A}$ & B & $\mathrm{C}$ & $\bar{D}$ & $E$ & $\overline{E o M_{1}}$ & $\mathrm{EoM}_{2}$ & \\
\hline Test 1 & 30 & 0 & 40 & 0.5 & 0.1 & 24.23 & 24.80 & 27.79 \\
\hline Test 2 & 30 & 200 & 50 & 1 & 0.3 & 25.67 & 26.42 & 28.31 \\
\hline Test 3 & 30 & 400 & 60 & 2 & 0.5 & 30.93 & 30.95 & 29.81 \\
\hline Test 4 & 30 & 600 & 70 & 3 & 1 & 57.04 & 62.37 & 35.49 \\
\hline Test 5 & 60 & 0 & 50 & 2 & 1 & 27.96 & 31.09 & 29.37 \\
\hline Test 6 & 60 & 200 & 40 & 3 & 0.5 & 26.94 & 31.21 & 29.20 \\
\hline Test 7 & 60 & 400 & 70 & 0.5 & 0.3 & 29.23 & 31.15 & 29.58 \\
\hline Test 8 & 60 & 600 & 60 & 1 & 0.1 & 30.40 & 30.93 & 29.73 \\
\hline Test 9 & 120 & 0 & 60 & 3 & 0.3 & 49.92 & 51.74 & 34.12 \\
\hline Test 10 & 120 & 200 & 70 & 2 & 0.1 & 60.97 & 62.41 & 35.80 \\
\hline Test 11 & 120 & 400 & 40 & 1 & 1 & 28.58 & 28.56 & 29.12 \\
\hline Test 12 & 120 & 600 & 50 & 0.5 & 0.5 & 29.33 & 29.05 & 29.30 \\
\hline Test 13 & 240 & 0 & 70 & 1 & 0.5 & 48.38 & 48.50 & 33.70 \\
\hline Test 14 & 240 & 200 & 60 & 0.5 & 1 & 33.75 & 33.91 & 30.59 \\
\hline Test 15 & 240 & 400 & 50 & 3 & 0.1 & 56.44 & 57.04 & 35.08 \\
\hline Test 16 & 240 & 600 & 40 & 2 & 0.3 & 32.75 & 32.45 & 30.26 \\
\hline
\end{tabular}


For example, $(\mathrm{M})$ Factor=I $\mathrm{Level=i}$, the mean of the $\mathrm{S} / \mathrm{N}$ ratio of factor $I$ in level $i$, is given by Equation (2):

$$
(\mathrm{M})_{\text {Factor }=I}^{\text {Level }=i}=\frac{1}{n_{I i}} \sum_{j=1}^{n_{I i}}\left[\left(\frac{S}{N}\right)_{\text {Factor }=I}^{\text {Level }=i}\right]_{j}
$$

In Equation (2), nIi shows the number of views of factor $I$ in the level $i .\left(\frac{S}{N}\right)_{\text {Factor=I }}^{\text {Level=i }}$ is the S/N ratio of factor $I$ in level $i$, and its sequence of view in Table 3 is the $j$ th. Subsequently, the values of the S/N ratio were transferred into Equation (2) and the mean of the $\mathrm{S} / \mathrm{N}$ ratios of a certain factor in the $i$ th level, $(\mathrm{M})_{\mathrm{Factor}=I \text {, }}^{\mathrm{Level}=i}$ was obtained (Table 4). As seen from Table 4, the bold values show the maximum of the mean of the S/N ratios. Thus, it shows the optimum conditions for Ni extraction from lateritic ore.

Table 4. S/N ratio response table for Ni extraction

\begin{tabular}{|c|c|c|c|c|c|}
\hline \multirow{2}{*}{ Factor/Level } & \multicolumn{4}{|c|}{$\left[(\mathrm{S} / \mathrm{N})_{\text {Factor }}^{\text {Level }}\right]_{j}$} & \multirow[t]{2}{*}{$(\mathrm{M})_{\text {Factor }}^{\text {Level }}$} \\
\hline & $j=1$ & $j=2$ & $j=3$ & $j=4$ & \\
\hline $\mathrm{A} / \mathbf{1}$ & 27.79 & 28.31 & 29.81 & 35.49 & 30.35 \\
\hline $\mathrm{A} / 2$ & 29.37 & 29.20 & 29.58 & 29.73 & 29.47 \\
\hline $\mathrm{A} / 3$ & 34.12 & 35.80 & 29.12 & 29.30 & 32.09 \\
\hline $\mathrm{A} / 4$ & 33.70 & 30.59 & 35.08 & 30.26 & 32.41 \\
\hline $\mathrm{B} / \mathbf{1}$ & 27.79 & 29.37 & 34.12 & 33.70 & 31.24 \\
\hline$B / 2$ & 28.31 & 29.20 & 35.80 & 30.59 & 30.98 \\
\hline$B / 3$ & 29.81 & 29.58 & 29.12 & 35.08 & 30.90 \\
\hline$B / 4$ & 35.49 & 29.73 & 29.30 & 30.26 & 31.20 \\
\hline $\mathrm{C} / \mathbf{1}$ & 27.79 & 29.20 & 29.12 & 30.26 & 29.09 \\
\hline $\mathrm{C} / 2$ & 28.31 & 29.37 & 29.30 & 35.08 & 30.52 \\
\hline $\mathrm{C} / 3$ & 29.81 & 29.73 & 34.12 & 30.59 & 31.06 \\
\hline $\mathrm{C} / 4$ & 35.49 & 29.58 & 35.80 & 33.70 & 33.65 \\
\hline $\mathrm{D} / \mathbf{1}$ & 27.79 & 29.58 & 29.30 & 30.59 & 29.32 \\
\hline $\mathrm{D} / 2$ & 28.31 & 29.73 & 29.12 & 33.70 & 30.22 \\
\hline$D / 3$ & 29.81 & 29.37 & 35.80 & 30.26 & 31.31 \\
\hline $\mathrm{D} / 4$ & 35.49 & 29.20 & 34.12 & 35.08 & 33.47 \\
\hline $\mathrm{E} / \mathbf{1}$ & 27.79 & 29.73 & 35.80 & 35.08 & 32.10 \\
\hline $\mathrm{E} / 2$ & 28.31 & 29.58 & 34.12 & 30.26 & 30.57 \\
\hline$E / 3$ & 29.81 & 29.20 & 29.30 & 33.70 & 30.50 \\
\hline $\mathrm{E} / 4$ & 35.49 & 29.37 & 29.12 & 30.59 & 31.14 \\
\hline
\end{tabular}

Also, analysis of variance (ANOVA) statistical method was applied to experimental results to investigate the effect of factors on $\mathrm{Ni}$ extraction. The percentage contribution of each factor, QF, was given by Equation (3).

$$
\rho_{\mathrm{F}}=\frac{S S_{\mathrm{F}}-\left(D O F_{\mathrm{F}} V_{\mathrm{Er}}\right)}{S S_{\mathrm{T}}} \times 100
$$


In Equation (3), $D O F \mathrm{~F}$ is produced by subtracting one from the number of levels. The total sum of squares, the factorial sum of squares and the variance of error are symbolized as $S S_{\mathrm{T}}, S S_{\mathrm{F}}$ and $V_{\mathrm{Er}}$, respectively.

$$
S S_{\mathrm{T}}=\sum_{j=1}^{m}\left(\sum_{i=1}^{n} \mathrm{EoM}_{i}^{2}\right)_{j}-m n\left(\overline{\mathrm{EoM}}_{T}\right)^{2}
$$

In Equation (4), $m$ and $n$ represents the number of experiments and the number of repetitions, respectively. $\overline{\mathrm{EoM}}_{T}$ represents the average of total EoM.

$$
S S_{\mathrm{F}}=\frac{m n}{L} \sum_{k=I}^{L}\left(\overline{\operatorname{EoM}}_{k}^{F}-\overline{\mathrm{EoM}}_{T}\right)^{2}
$$

In Equation (5), $\overline{\mathrm{EoM}}_{k}^{F}$ is the average value of the experimental results of a certain factor in the $k$ th level. The variance of error, $V_{\mathrm{Er}}$, is given by Equation (6):

$$
V_{\mathrm{Er}}=\frac{S S_{\mathrm{T}}-\sum_{F=A}^{E} S S_{\mathrm{F}}}{m(n-1)}
$$

\section{Optimization Conditions}

For optimization of nickel extraction from lateritic ore, 16 tests were performed according to conditions given in Table2. By taking into account the number of experimental repetitions and results of metal extraction (EoM), the S/N ratios of each test condition were determined (Table 3). In Table 3, the maximum $S / N$ value was represented in bold. Subsequently, the $\mathrm{S} / \mathrm{N}$ ratio values were transferred into Equation (2) and the mean of the $\mathrm{S} / \mathrm{N}$ ratios were given in Table 4 . ${ }^{(\mathrm{M})}$ ) Factor refers to result of the effect of each level of each factor and the maximum values of these show the optimum conditions for nickel extraction. As a result of this, optimum conditions were given in Table 5. As seen from Table 5, an experiment was carried out to compare the results of test 10 and obtained optimum conditions. Consequently, it was determined that the value of the $\mathrm{S} / \mathrm{N}$ ratio of optimum conditions was greater than the value of the $\mathrm{S} / \mathrm{N}$ ratio of test 10 . Additionally, the average of EoM rises from $61.69 \%$ to $90.66 \%$. Each level of each factor and corresponding the mean of the S/N ratio values which obtained from Table 4 were plotted and shown in Figure 2-6.

Table 5. The optimum condition for Ni extraction

\begin{tabular}{|l|cccccccc|}
\cline { 2 - 9 } \multicolumn{1}{c|}{} & A & B & C & D & E & EoM & EoM & S/N \\
\hline Test 10 & 120 & 200 & 70 & 2 & 0.1 & 60.97 & 62.41 & 35.80 \\
Optimization condition & 240 & 0 & 70 & 3 & 0.1 & 89.60 & 91.71 & 39.15 \\
\hline
\end{tabular}

Table 6. The average of the experimental results of a certain factor in the $k$ th level and the average of total $E o M(E o M T)$ for Ni extraction

\begin{tabular}{|l|llllll|}
\hline Leve1 & $\overline{\mathbf{E o M}}_{\boldsymbol{K}}^{\mathrm{A}}$ & $\overline{\mathbf{E o M}}_{\boldsymbol{K}}^{\mathrm{B}}$ & $\overline{\mathbf{E o M}}_{\boldsymbol{K}}^{\mathrm{C}}$ & $\overline{\mathbf{E o M}}_{\boldsymbol{K}}^{\mathrm{D}}$ & $\overline{\mathbf{E o M}}_{\boldsymbol{K}}^{\mathrm{E}}$ & $\overline{\mathbf{E o M}}_{\mathbf{T}}$ \\
\hline Leve1 1 & 35.30 & 38.33 & 28.69 & 29.43 & 43.40 & 37.66 \\
Leve1 2 & 29.86 & 37.66 & 35.38 & 33.43 & 34.92 & \\
Leve1 3 & 42.57 & 36.61 & 36.57 & 38.69 & 34.41 & \\
Leve1 4 & 42.90 & 38.04 & 50.00 & 49.09 & 37.91 & \\
\hline
\end{tabular}




\section{Leaching time}

Figure 2 show s the effect of leaching time on the $\mathrm{S} / \mathrm{N}$ ratio for extraction of nickel from lateritic ore in hydrochloric acid solution with hydrogen peroxide. As seen from Figure 2, it was determined that the optimum leaching time was $240 \mathrm{~min}$. It may be concluded that an increase in time of the presence of ore particles in solution causes to increase the extraction of nickel. Thus, the amount of metal ions dissolved from particle that passes into solution increases with time.

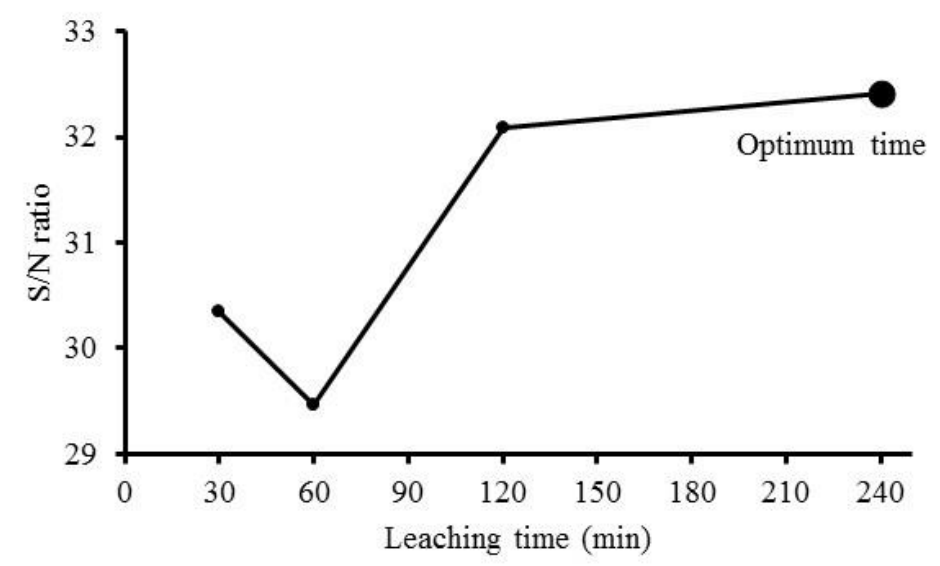

Figure 2. Effect of leaching time on the $\mathrm{S} / \mathrm{N}$ ratio for extraction of nickel from lateritic ore

\section{Stirring speed}

In Figure 3, effect of stirring speed on the $\mathrm{S} / \mathrm{N}$ ratio for extraction of nickel from lateritic ore in hydrochloric acid solution with hydrogen peroxide was shown. As seen from Figure 3, it was determined that no significant effect of stirring speed on the extraction of nickel. Thus, the optimum condition was provided by no stirring. Although a kinetic investigation w as not performed in this study, it may be considered the negligible effect of stirring speed on extraction of nickel from lateritic ore could stem from dissolution mechanism. Georgiou and Papangelakis (1998) expressed that stirring speed had a negligible effect on the rate of nickel dissolution from limonitic laterite.

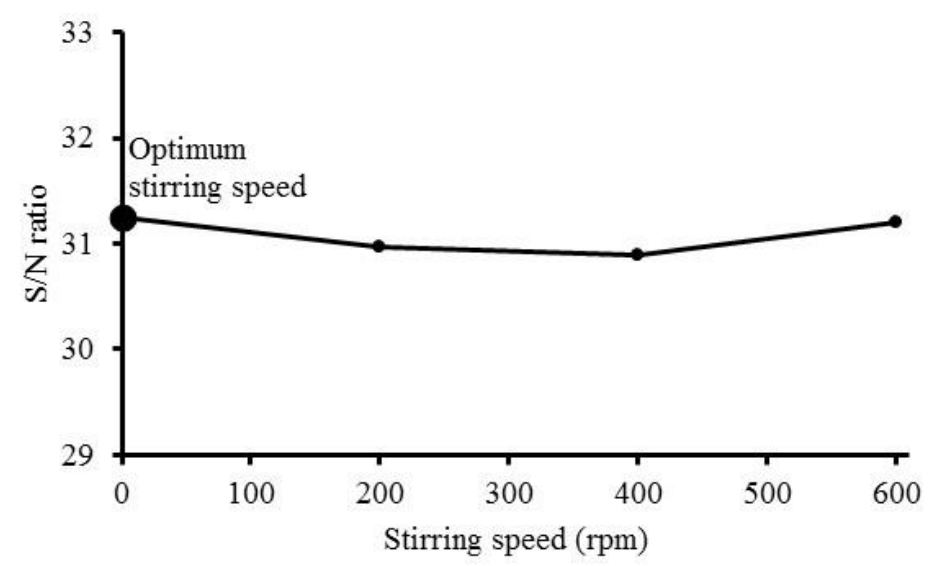

Figure 3. Effect of stirring speed on the $\mathrm{S} / \mathrm{N}$ ratio for extraction of nickel from lateritic ore 


\section{Temperature}

The plot of the effect of temperature on the $\mathrm{S} / \mathrm{N}$ ratio for the extraction of nickel from lateritic ore in hydrochloric acid solution with hydrogen peroxide was shown in Figure 4. As seen from Figure 4, it was determined that the optimum leaching temperature was $70^{\circ} \mathrm{C}$. The extraction of nickel increased with an increase in temperature of solution. As known, temperature increases reaction rate and equilibrium constant. However, rapid decomposition of hydrogen peroxide occurs at higher temperatures (Antonijevic et al., 1997; Mahajan et al., 2007).

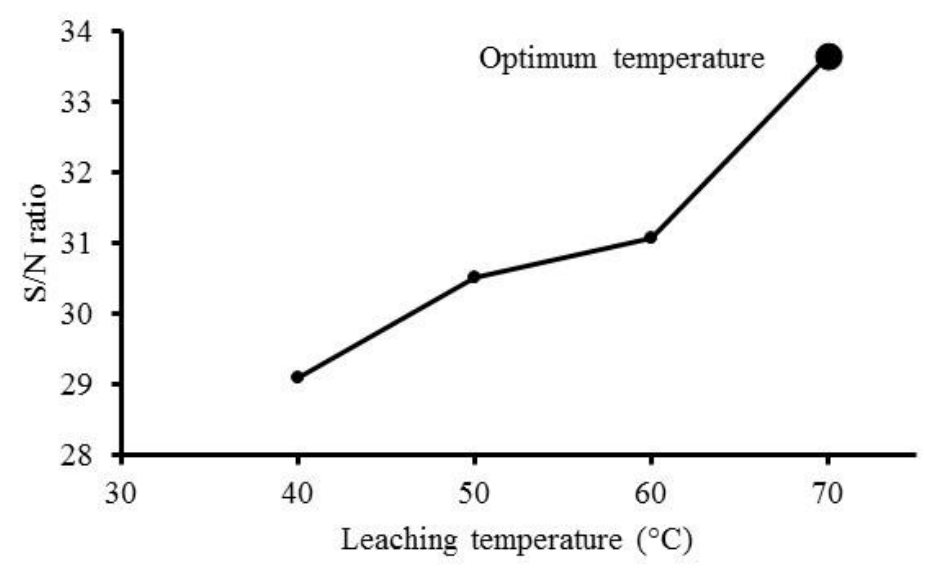

Figure 4. Effect of temperature on the $\mathrm{S} / \mathrm{N}$ ratio for extraction of nickel from lateritic ore

\section{Acid concentration}

Figure 5 shows the effect of acid concentration on the $\mathrm{S} / \mathrm{N}$ ratio for extraction of nickel from lateritic ore in hydrochloric acid solution with hydrogen peroxide. As seen from Figure 5, it was determined that the optimum hydrochloric acid concentration was $3 \mathrm{M}$. The results presented in Figure 5 show that, S/N ratio values increase as acid concentration increases. Aydogan (2006) and Antonijevic et al. (1997) expressed that hydrogen peroxide shows oxidative action in acidic solutions.

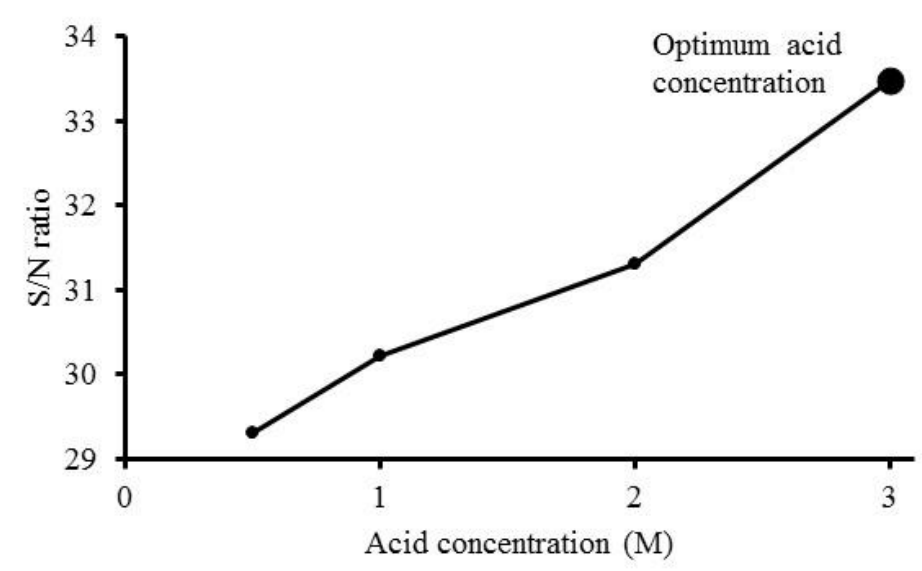

Figure 5. Effect of acid concentration on the $\mathrm{S} / \mathrm{N}$ ratio for extraction of nickel from lateritic ore 


\section{$\mathrm{H}_{2} \mathrm{O}_{2}$ concentration}

The plot of the effect of $\mathrm{H}_{2} \mathrm{O}_{2}$ concentration on the $\mathrm{S} / \mathrm{N}$ ratio for extraction of nickel from lateritic ore in hydrochloric acid solution with hydrogen peroxide was shown in Figure 6. As seen from Figure 6, it w as determined that the optimum $\mathrm{H}_{2} \mathrm{O}_{2}$ concentration was $0.1 \mathrm{M}$. The results presented in Figure 6 show that, $\mathrm{S} / \mathrm{N}$ ratio values decreases as $\mathrm{H}_{2} \mathrm{O}_{2}$ concentration increases.

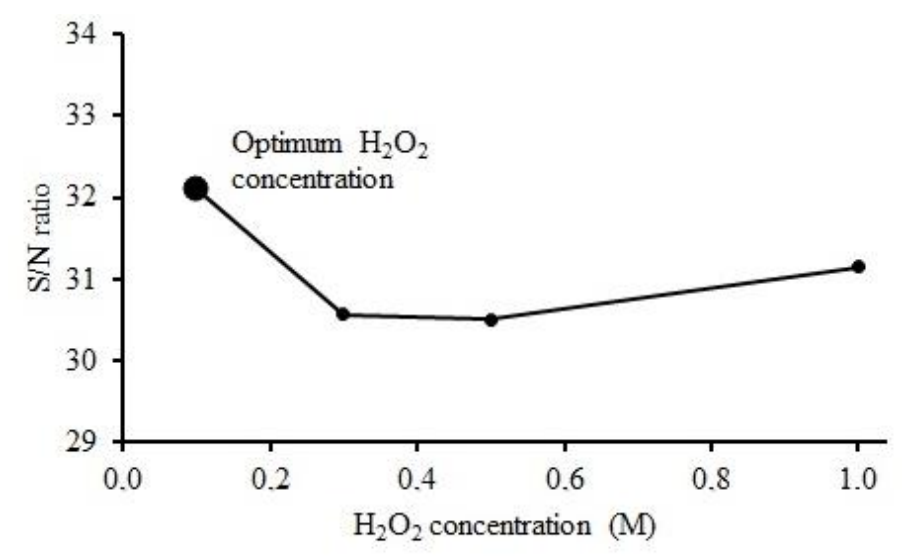

Figure 6. Effect of $\mathrm{H}_{2} \mathrm{O}_{2}$ concentration on the $\mathrm{S} / \mathrm{N}$ ratio for extraction of nickel from lateritic ore

\section{Percentage of Contribution}

In order to determine the percentage of the contribution of each factor, the average values of the experimental results of a certain factor in the $k$ th level $\left(\overline{\mathrm{EoM}}_{K}^{\mathrm{F}}\right)$ were obtained using EoMivalues in Table 3 and given in Table 6 . After this, the factorial sum of squares, $S S_{F}$, for each factor was calculated. The total sum of squares, $S S_{\mathrm{T}}$, w as determined. After this process, using $S S_{\mathrm{F}}$ and $S S_{\mathrm{T}}$ values, $V \mathrm{Er}$ w as obtained. Consequently, the percentage contribution of each factor, $\rho \mathrm{F}, \mathrm{w}$ as determined. All of the obtained values were given in Table 7. As seen from Table 7, the importance order can be seen as; temperature, acid concentration, leaching time, $\mathrm{H}_{2} \mathrm{O}_{2}$ concentration and stirring speed.

Table 7. Percentage contribution of each factor

\begin{tabular}{|l|lllll|}
\hline Factor & $D O F_{\mathrm{F}}$ & $S S_{\mathrm{F}}$ & $\rho_{\mathrm{F}}(\%)$ & $S S_{\mathrm{T}}$ & $V_{\mathrm{Er}}$ \\
\hline Leaching time (min) & 3 & 943.80 & 18.693 & 5048.95 & 1.96 \\
Stirring speed (rpm) & 3 & 13.57 & 0.269 & & \\
Temperature $\left({ }^{\circ} \mathrm{C}\right)$ & 3 & 1912.98 & 37.889 & & \\
Acid concentration (M) & 3 & 1738.65 & 34.436 & & \\
$\mathrm{H}_{2} \mathbf{O}_{2}$ concentration (M) & 3 & 408.64 & 8.094 & & \\
Error & & 31.30 & 0.620 & & \\
\hline
\end{tabular}

\section{CONCLUSION}

The optimum conditions of extraction of nickel from lateritic ore in hydrochloric acid solution with hydrogen peroxide were determined by Taguchi method. The effects of some parameters (leaching time, stirring speed, temperature, hydrochloric acid concentration and hydrogen peroxide concentration) on extraction of nickel were investigated. The optimum conditions determined by Taguchi method were; leaching time of $240 \mathrm{~min}$, a temperature of $70{ }^{\circ} \mathrm{C}$, hydrochloric acid concentration of $3 \mathrm{M}$, hydrogen peroxide concentration of $0.1 \mathrm{M}$ and without stirring. As a result of experimental results, it was demonstrated that, extraction of nickel was obtained with a recovery of $90.66 \%$ in optimum conditions. 
In addition, analysis of variance (ANOVA) was applied to experimental results. Percentage contributions of each factor for extraction of nickel were: temperature $(37.889 \%)$, acid concentration $(34.436 \%)$, leaching time $(18.693 \%), \mathrm{H}_{2} \mathrm{O}_{2}$ concentration $(8.094 \%)$ and stirring speed $(0.269 \%)$. In point of these results, the extraction of nickel is most dependent by temperature.

\section{REFERENCES}

Abali, Y., Copur, M., Yavuz, M. 2006, "Determination of The Optimum Conditions for Dissolution of Magnesite with H2SO4 Solutions", Ind. J. of Chem. Technol., Vol. 13, pp. 391-397.

Abali, Y., Bayca, S. U., Arisoy, K., Vaizogullar, A.I., 2011, “Optimization of Dolomite Ore Leaching in Hydrochloric Acid Solutions", Physicochemical Problems of Mineral Processing, Vol. 46, pp. 253-262.

Agacayak, T., Zedef, V., Aydogan, S., 2011, “Leaching of Lateritic Nickel Ores of Karacam (EskisehirTurkey) with Hydrochloric Acid", 11th International Multidisciplinary Scientific GeoConference\&EXPO SGEM, Modern Management of Mine Producing, Geology and Environmental Protection, Albena-Varna/Bulgaria. Vol. 1, pp. 1155-1162, 19-25 June 2011.

Agacayak, T., Zedef, V., 2012, "Dissolution Kinetics of a Lateritic Nickel Ore in Sulphuric Acid Medium", Acta Montanistica Slovaca, Vol. 17 (1), pp. 33-41.

Agacayak, T., Zedef, V., 2013, "Leaching of a Turkish lateritic nickel ore in nitric acid solution", Mine Planning and Equipment Selection, Proceedings of the 22nd MPES Conference, Dresden, Germany.

Agatzini-Leonardou, S., Zafiratos, I. G., 2004, "Beneficiation of a Greek Serpentinic Nickeliferous Ore Part II. Sulfuric Acid Heap and Agitation Leaching", Hydrometallurgy, Vol. 74, pp. 267-275.

Antonijevic, M. M., Dimitrijevic, M., Jankovic, Z., 1997, “Leaching of Pyrite with Hydrogen Peroxide in Sulfuric Acid", Hydrometallurgy, Vol. 46, pp. 71-83.

Asl, M.S., Kakroudi, M. G., Golestani-Fard, F., Nasiri H. 2015, “A Taguchi Approach to The Influence of Hot Pressing Parameters and SiC Content on The Sinterability of ZrB2-Based Composites", International Journal of Refractory Metals and Hard Materials, Vol. 51, pp. 81-90.

Ata, O. N., Colak, S., Ekinci, Z., Çopur, M., 2001, "Determination of The Optimum Conditions for Leaching of Malachite Ore in H2SO4 Solutions", Chemical Engineering \& Technology, Vol. 24 (4), pp. 409-413.

Atil, H., Unver, Y., 2000, “A Different Approach of Experimental Design: Taguchi Method", Pakistan Journal of Biological Sciences, Vol. 3 (9), pp. 1538-1540.

Ayanda, O. S., Adekola, F. A., Baba, A. A., Fatoki, O. S., Ximba, B. J., 2011, “Comparative Study of the Kinetics of Dissolution of Laterite in Some Acidic Media", J. of Miner. \& Mater. Character. \& Eng., Vol. 10 (15), pp. 1457-1472.

Aydogan, S., 2006, "Dissolution Kinetics of Sphalerite with Hydrogen Peroxide in Sulphuric Acid Medium", Chemical Engineering Journal, Vol. 123 (3), pp. 65-70.

Babaei-Dehkordi, A., Moghaddam, J., Mostafaei, A., 2013, “An Optimization Study on The Leaching of Zinc Cathode Melting Furnace Slag in Ammonium Chloride by Taguchi Design and Synthesis of ZnO Nanorods via Precipitation Methods", Materials Research Bulletin, Vol. 48 (10), pp. $4235-4247$.

Behera, S. K., Sukla, L. B., Mishra, B. K., 2010, “Leaching of Nickel Laterite Using Fungus Mediated Organic Acid and Synthetic Organic Acid: A Comparative Study", Proceedings of the XI International Seminar on Mineral Processing Technology, pp. 946-954.

Bese, A. V., Borulu, N., Copur, M., Colak, S., Ata, O. N., 2010, “Optimization of Dissolution of Metals from Waelz Sintering Waste (WSW) by Hydrochloric Acid Solutions", Chemical Engineering Journal, Vol. 162 (2), pp. 718-722.

Brand, N. W., Butt, C. R. M., Elias, M., 1998, “Nickel Laterites: Classification and Features”, J. of Australian Geo. and Geoph., Vol. 17, pp. 81-88. 
Chen, S., Guo, X., Shi, W., Li, D., 2010, “Extraction of Valuable Metals From Low-Grade Nickeliferous Laterite Ore by Reduction Roasting-Ammonia Leaching Method", Journal of Central South University of Technology, Vol. 17 (4), pp. 765-769.

Copur, M., 2002, “An Optimization Study of Dissolution of Zn and Cu in ZnS Concentrate with HNO3 Solutions", Chemical and Biochemical Engineering Quarterly, Vol. 16 (4), pp. 191-197.

Dalvi, A. D., Bacon, W., Osborne, R. C., 2004, “The Past and The Future of Nickel Laterites”, PDAC 2004 International Conference Trade Show and Investors Exchange, Toronto, CANADA.

Deepatana, A., Tang, J. A., Valix, M., 2006, “Comparative Study of Chelating Ion Exchange Resins for Metal Recovery from Bioleaching of Nickel Laterite Ores", Minerals Engineering, Vol. 19(2), pp. 1280-1289.

Demir, F., Donmez, B. 2008, “Optimization of The Dissolution of Magnesite in Citric Acid Solutions”, International Journal of Mineral Processing, Vol. 87 (1), pp. 60-64.

Dogan, T. H., Yartasi, A., 2014, "Optimization of Dissolution of Ulexite in Phosphate Acid Solutions", Journal of the Chemical Society of Pakistan, Vol. 36 (4), pp. 601-605.

Donmez, B., Celik, C., Colak, S. Yartasi, A., 1998, “The Dissolution Optimization of Copper from Anode Slime in H2SO4 Solutions", Industrial \& Engineering Chemistry Research, Vol. 37 (8), pp. 3382-3387.

Elias, M., 2002, “Nickel Laterite Deposits - Geological Overview, Resources and Exploitation, in: Giant Ore Deposits: Characteristics, Genesis and Exploration". Hobart, University of Tasmania, CODES Special Publication, pp. 205-220.

Georgiou, D., Papangelakis, G. V., 1998, "Sulphuric Acid Pressure Leaching of A Limonitic Laterite: Chemistry and Kinetics", Hydrometallurgy, Vol. 49, pp. 23-46.

Gleeson, S. A., Butt, C. R. M., Elias, M., 2003, “Nickel Laterites: A Review”. SEG New sletter, Soc. of Econ. Geo., Vol. 54, pp. 12-18.

Golightly, J. P., 1981, “Nickeliferous Laterite Deposits”, Economic Geology Vol. 75 (1), pp. $710-735$.

Guo, Q., Qu, J., Han, B., Zhang, P., Song, Y., Qi, T., 2015, “Innovative Technology for Processing Saprolitic Laterite Ores by Hydrochloric Acid Atmospheric Pressure Leaching”, Minerals Engineering, Vol. 71, pp. 1-6.

Ilyas, S., Bhatti, H. N., Bhatti, I. A., Sheikh, M. A., Ghauri, M. A., 2010, “Bioleaching of Metal Ions from Low Grade Sulphide Ore: Process Optimization by Using Orthogonal Experimental Array Design", African Journal of Biotechnology, Vol. 9 (19), pp. 2801-2810.

Kursunoglu, S., Kaya, M., 2015, “Dissolution Behavior of Caldag Lateritic Nickel Ore Subjected to a Sequential Organic Acid Leaching Method", Journal of Minerals, Metallurgy, and Materials, Vol. 22 (11), pp. 1131-1140.

Landers, M., Gilkes, R. J., Wells, M. 2009, “Dissolution Kinetics of Dehydroxylated Nickeliferous Goethite from Limonitic Lateritic Nickel Ore", Applied Clay Science, Vol. 42 (3), pp. 615-624.

Li, J., Xiong, D., Chen, H., Wang, R., Liang, Y., 2012, “Physicochemical Factors Affecting Leaching of Laterite Ore in Hydrochloric Acid", Hydrometallurgy, Vol. 129 (130), pp. 14-18.

Luo, W., Feng, Q., Ou, L., Zhang, G., Chen, Y. 2010, “Kinetics of Saprolitic Laterite Leaching by Sulphuric Acid at Atmospheric Pressure", Minerals Engineering, Vol. 23 (6), pp. 458-462.

Ma, B., Wang, C., Yang, W., Yang, B., Zhang, Y., 2013, “Selective Pressure Leaching of Fe (II)-rich Limonitic Laterite Ores from Indonesia Using Nitric Acid", Minerals Engineering, Vol. 45, pp. 151-158.

Mahajan, V., Misra, M., Zhong, K., Fuerstenau, M.C., 2007, “Enhanced Leaching of Copper from Chalcopyrite in Hydrogen Peroxide-Glycol System", Minerals Engineering, Vol. 20, pp. 670674.

McDonald, R. G., Whittington, B. I. 2008a, “Atmospheric acid leaching of nickel laterites review (Part I). Sulphuric acid technologies", Hydrometallurgy, Vol. 91 (1/4), pp. 35-55.

McDonald, R. G., Whittington, B. I. 2008b, “Atmospheric Acid Leaching of Nickel Laterites Review . Part II. Chloride and Bio-technologies", Hydrometallurgy, Vol. 91, pp. 56-69. 
Moghaddam, J., Sarraf-Mamoory, R., Abdollahy, M., Yamini, Y. 2006, “Purification of Zinc Ammoniacal Leaching Solution by Cementation: Determination of Optimum Process Conditions with Experimental Design by Taguchi's Method", Separation and Purification Technology, Vol. 51 (2), pp. 157-164.

Mohammadreza, F., Mohammad, N., Ziaeddin, S. S., 2014, “Nickel Extraction from Low Grade Laterite by Agitation Leaching at Atmospheric Pressure", International Journal of Mining Science and Technology, Vol. 24 (4), pp. 543-548.

Olanipekun, E. O., 2000, “Kinetics of Leaching Laterite", International Journal of Mineral Processing, Vol. 60, pp. 9-14.

Park, K. H., Nam, C. W. 2008, "Status and Prospect of Nickel Resources and Processing", Trending Metals Mater. Eng., Vol. 21, pp.1-9.

Phadke M. S., 1989, Quality Engineering using Robust Design, Prentice Hall, New Jersey, pp. 61-292.

Roy, R. K., 1995, A Primer on the Taguchi Method, Van Nostrand Reinhold, New York.

Rubisov, D. H., Krowinkel, J. M., Papangelakis, V. G., 2000, “Sulphuric Acid Pressure Leaching of Laterites Universal Kinetics of Nickel Dissolution for Limonites and Limonitic/Saprolitic Blends", Hydrometallurgy, Vol. 58 (1), pp. 1-11.

Safarzadeh, M. S., Moradkhani, D., Ilkhchi, M. O., Golshan, N. H. 2008, “Determination of The Optimum Conditions for The Leaching of Cd-Ni Residues from Electrolytic Zinc Plant Using Statistical Design of Experiments", Separation and Purification Technology, Vol. 58 (3), pp. 367-376.

Sagapoa, C. V., Imai, A., Watanabe, K., 2011, “Laterization Process of Ultramafic Rocks in Siruka, Solomon Islands", Journal of Novel Carbon Resource Sciences, Vol. 3, pp. 32-39.

Sahu, S., Kavuri, N. C., Kundu, M., 2011, “Dissolution Kinetics of Nickel Laterite ore Using Different Secondary Metabolic Acids", Brazilian Journal of Chemical Engineering, Vol. 28 (2), pp. 251-258.

Soler, J. M., Cama, J., Galí, S. Meléndez, W., Ramírez, A., Estanga, J., 2008, “Composition and Dissolution Kinetics of Garnierite from The Loma de Hierro Ni-laterite Deposit, Venezuela", Chemical Geology, Vol. 249 (1/2), pp. 191-202.

Stopic, S., Friedrich, B., Fuchs, R., 2002, “Kinetics of Sulphuric Acid Leaching of the Serbian Nickel Laterite Ore under Atmospheric Pressure", Metalurgica J. of Metall., Vol. 8 (3), pp. 235-244.

Sukla, L. B., Panchanadikar, V., 1993, “Bioleaching of Lateritic Nickel Ore Using A Heterotrophic MicroOrganism", Hydrometallurgy, Vol. 32, pp. 373-379.

Taguchi, G., 1987, System of Experimental Design, Quality Resources, New York.

Thubakgale, C. K., Mbaya, R. K. K., Kabongo, K., 2013, “A Study of Atmospheric Acid Leaching of a South African Nickel Laterite", Minerals Engineering, Vol. 54, pp. 79-81.

Wang, B., Guo, Q., Wei, G., Zhang, P., Qu, J., Qi, T. 2012, “Characterization and Atmospheric Hydrochloric Acid Leaching of A Limonitic Laterite from Indonesia”, Hydrometallurgy, Vol. 129-130, pp. 7-13.

Zhai, Y., Mu, W., Liu, Y., Xu, Q. 2010, “A Green Process for Recovering Nickel From Nickeliferous Laterite Ores", Transactions of Nonferrous Metals Society of China, Vol. 20, pp. 65-70.

Zolfaghari, G., Esmaili-Sari, A., Anbia, M., Younesi, H., Amirmahmoodi, S., Ghafari-Nazari, A., 2011, "Taguchi Optimization Approach for $\mathrm{Pb}(\mathrm{II})$ and $\mathrm{Hg}$ (II) Removal from Aqueous Solutions Using Modified Mesoporous Carbon", Journal of Hazardous Materials, Vol. 192 (3), pp. 10461055.

Zuniga, M., Parada, F., Asselin, E., 2010, “Leaching of A Limonitic Laterite in Ammoniacal Solutions with Metallic Iron”, Hydrometallurgy, Vol. 104, pp. 260-267. 